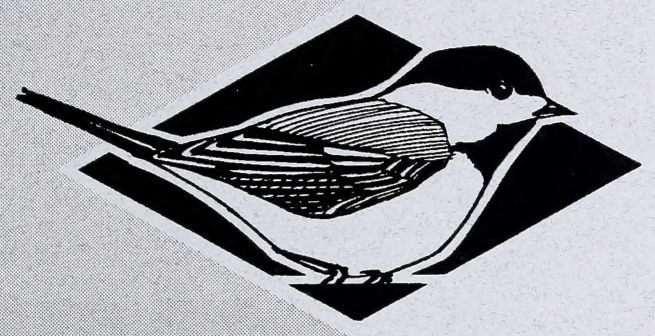

DEC 221997

\title{
Status of the Piping Plover (Charadrius melodus) in Alberta
}

David R. C. Prescott
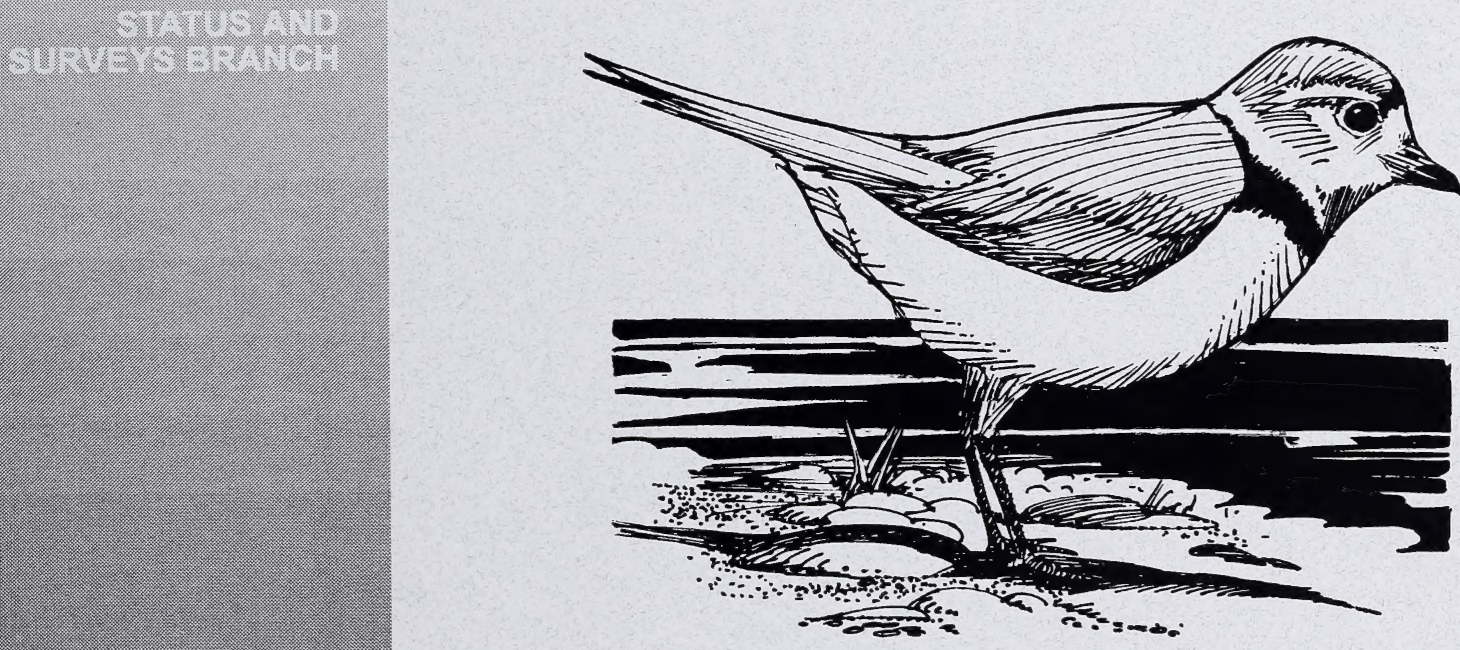

Alberta Wildlife Status Report No. 1 
Digitized by the Internet Archive in 2015

https://archive.org/details/statusofpipingpl00pres 


\title{
Status of the Piping Plover (Charadrius melodus) in Alberta
}

\author{
David R. C. Prescott
}

Alberta Wildlife Status Report No. 1

\author{
Published By:
}
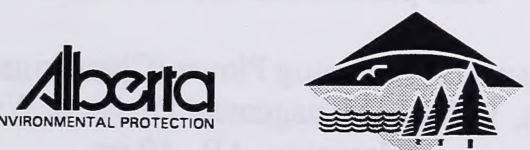
Publication No. T/346

ISBN: 0-7732-5095-6

ISSN: 1206-4912

Series Editor: David R. C. Prescott

Illustrations: Brian Huffman

For copies of this report, contact:

Information Centre - Publications

Alberta Environmental Protection

Natural Resources Service

Main Floor, Bramalea Building

9920 - 108 Street

Edmonton, Alberta, Canada T5K 2M4

Telephone: (403) 422-2079

\section{OR}

Communications Division Alberta Environmental Protection

\#100, 3115 - 12 Street NE

Calgary, Alberta, Canada T2E 7J2

Telephone: (403) 297-3362

This publication may be cited as:

Prescott, D. R. C. 1997. Status of the Piping Plover (Charadrius melodus) in Alberta. Alberta Environmental Protection, Wildlife Management Division, Wildlife Status Report No. 1, Edmonton, AB. 19 pp. 


\section{PREFACE}

Every five years, the Wildlife Management Division of Alberta Natural Resources Service reviews the status of wildlife species in Alberta. These overviews, which have been conducted in 1991 and 1996, assign individual species to "color" lists which reflect the perceived level of risk to populations which occur in the province. Such designations are determined from extensive consultations with professional and amateur biologists, and from a variety of readily-available sources of population data. A primary objective of these reviews is to identify species which may be considered for more detailed status determinations.

The Alberta Wildlife Status Report Series is an extension of the 1996 Status of Alberta Wildlife review process, and provides comprehensive current summaries of the biological status of selected wildlife species in Alberta. Priority is given to species that are potentially at risk in the province (Red or Blue listed), that are of uncertain status (Status Undetermined), or which are considered to be at risk at a national level by the Committee on the Status of Endangered Wildlife in Canada (COSEWIC).

Reports in this series are published and distributed by the Wildlife Management Division of Alberta Environmental Protection, and are intended to provide detailed and up-to-date information which will be useful to resource professionals for managing populations of species and their habitats in the province. The reports are also designed to provide current information which will assist the proposed Alberta Endangered Species Conservation Committee to identify species that may be formally designated as endangered or threatened under the Alberta Wildlife Act. To achieve these goals, the reports have been authored and/or reviewed by individuals with unique local expertise in the biology and management of each species. 


\section{EXECUTIVE SUMMARY}

The Piping Plover (Charadrius melodus) is currently listed as either a "threatened" or "endangered" species throughout its range in North America, and is designated as "endangered" under the Alberta Wildlife Act. This report reviews information on the Piping Plover in Alberta, as a step in updating the status of this species in the province.

The Piping Plover breeds on sparsely-vegetated beaches on larger alkaline lakes in the central and southern parts of the province. Populations fluctuate from year to year depending on the availability of suitable breeding habitat, but generally number less than 300 adults. Over the past decade, approximately half of the provincial breeding population has been found on nine lakes. Populations on a given lake are dynamic, changing annually with variation in water levels and the presence of suitable nesting substrates.

Although continental populations have declined, there is no evidence of a population decline in Alberta. However, there are a number of factors which may jeopardize populations in this province, including vegetation encroachment and human-induced changes in basin hydrology, industrial development of shorelines and adjacent areas, disturbance from livestock grazing and human recreational activities, predation on eggs and young, and degradation of habitat on the wintering range.

The Piping Plover is apparently not in imminent danger of extirpation in Alberta. However, the small population that is concentrated on a few major lakes, coupled with declining populations elsewhere and potential threats to local populations, suggests that the Alberta population remains vulnerable to future declines. Continued monitoring of known breeding locations is needed to clarify population trends and potential factors limiting population size in the province. 


\section{ACKNOWLEDGEMENTS}

I thank G. Erickson and E. Hofman (Alberta Natural Resources Service), K. Schmitt, B. Ilnicki (Ducks Unlimited Canada), B. Jones (Manitoba Department of Natural Resources), E. Wiltse (Saskatchewan Environment and Resource Management), I. Richardson (University of Alberta), S. Haig (U. S. Geological Survey), J. Plissner (Oregon State University), P. Goossen (Canadian Wildlife Service), R. Wells (Alberta Environmental Protection, Resource Data Division) and A. Murphy for supplying unpublished information used in this report. R. Andrews, S. Brechtel and R. Bjorge (Alberta Natural Resources Service), E. Ewaschuk (Land Stewardship Centre of Canada) and P. Goossen offered comments on earlier drafts of the manuscript. I also thank J. Horb for producing the maps and D. Ryerson (Natural Resources Service) for editorial and production assistance.

Preparation of this report was funded by the Wildlife Management Enhancement Fund of Alberta Natural Resources Service and the Alberta Conservation Association. 


\section{TABLE OF CONTENTS}

PREFACE iii

EXECUTIVE SUMMARY iv

ACKNOWLEDGEMENTS $\mathrm{v}$

INTRODUCTION

HABITAT

CONSERVATION BIOLOGY

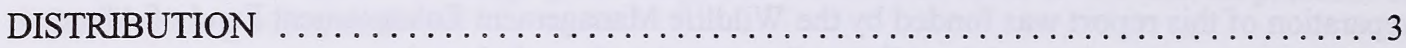

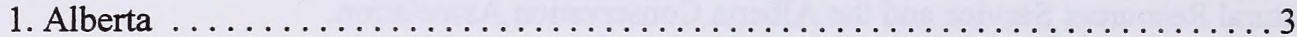

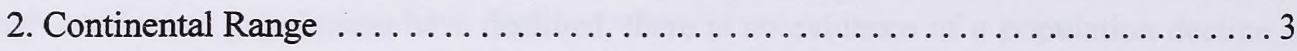

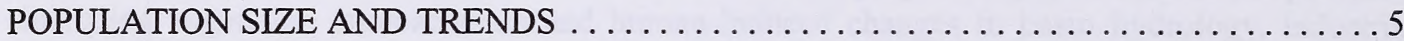

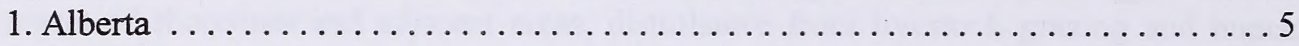

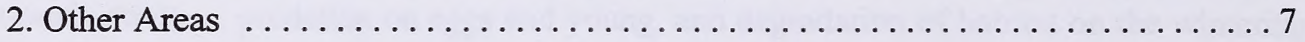

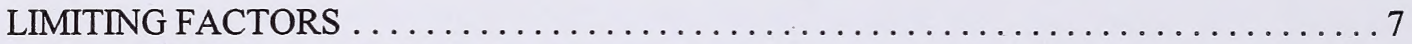

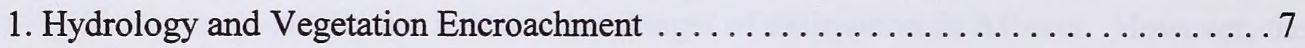

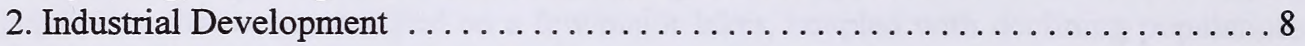

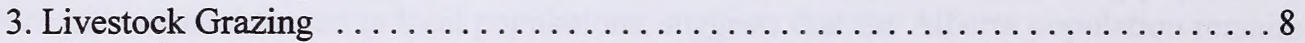

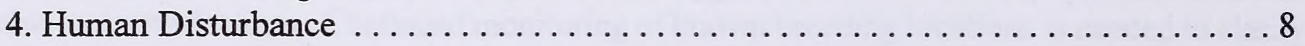

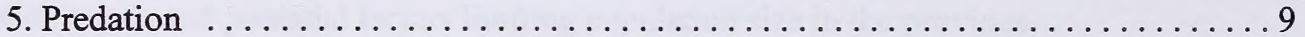

6. Development of Habitat on the Winter Range $\ldots \ldots \ldots \ldots \ldots \ldots \ldots$

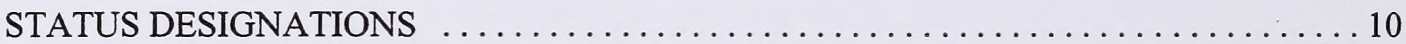

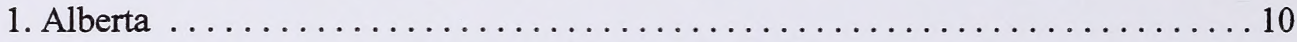

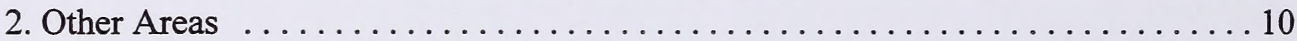

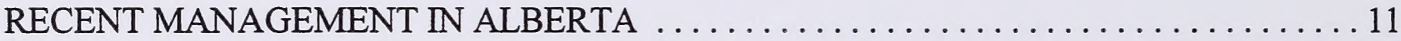

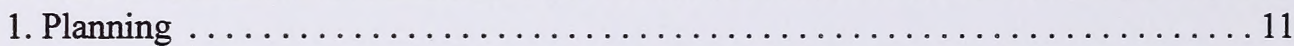

2. Habitat Securement, Protection and Enhancement $\ldots \ldots \ldots \ldots \ldots \ldots \ldots \ldots \ldots \ldots$

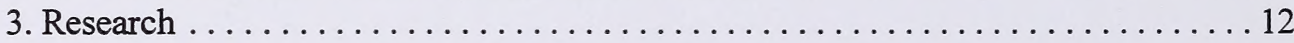

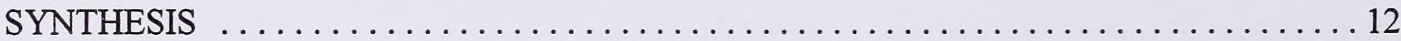

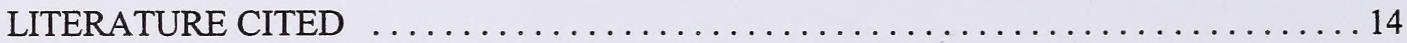

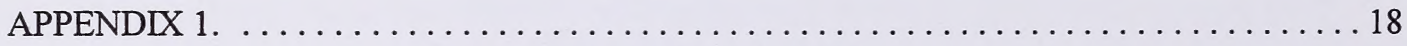

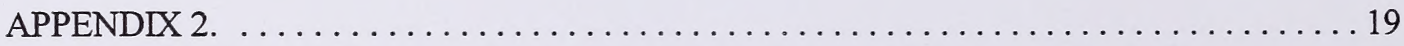




\section{INTRODUCTION}

Populations of the Piping Plover (Charadrius melodus) have declined across much of North America in recent years, and the species is now considered to be "endangered*" or "threatened" in all areas of its breeding and wintering range within the United States and Canada. The species is currently designated as being "endangered" under the Alberta Wildlife Act.

In the past few years, much information about the biology of the Piping Plover has been gathered in Alberta, and from other breeding areas on the Great Plains. This information is reviewed here, as a first step in updating the status of the species in the province.

\section{HABITAT}

In Alberta, and elsewhere on the Great Plains, the Piping Plover inhabits shorelines and islands of large alkaline lakes (Haig 1992, Wershler and Wallis 1987, Weseloh and Weseloh 1983, Whyte 1985). Nesting typically occurs on gravel substrates in areas with relatively wide, sparsely-vegetated beaches (Dundas 1995, Prindiville Gaines and Ryan 1988, Wershler and Wallis 1987, Whyte 1985). Suitable nesting areas are usually localized on lakes, so Piping Plovers typically have a clumped distribution, with several birds nesting in close proximity (Alberta Fish and Wildlife 1991a).

The availability of suitable nesting substrates for Piping Plovers is intimately linked to seasonal and annual variations in water level on nesting lakes (Wershler and Wallis 1987). Periodic high-water events may restrict beach width and temporarily limit the availability of nesting habitat, but eventual recession of water levels exposes unvegetated shorelines and gravel deposits which provide breeding habitat for several years thereafter. Prolonged periods of low water allows vegetation to encroach onto nesting beaches, which reduces habitat suitability until high water returns.

Annual variations in water levels are typical in prairie ecosystems, and habitat availability for plovers on a given lake will differ between years. Thus, an absence of birds at a site in a particular year does not necessarily mean the habitat is permanently unsuitable, provided that the natural hydrology of a basin is maintained. The large saline basins occupied by Piping Plovers on the Canadian prairies are generally unsuitable for cultivation, and have not been drained or modified to the same extent as small, fresh wetlands in this region. However, hydrological changes resulting from human activities may threaten the suitability of habitat on several traditional nesting lakes in Alberta (see "Limiting Factors"). Thus, the possibility of slow, long-term declines in habitat availability is a concern for Piping Plovers in this province.

\section{CONSERVATION BIOLOGY}

Piping Plovers arrive on the breeding grounds in Alberta in late April (Heckbert 1994, Heckbert and Cantelon 1995, Pinel et al. 1991). Males establish territories that average about 3 ha in size (Whyte 1985). Most first nests are initiated in early May, but eggs have been reported as early as 30 April in this province (Heckbert 1994). Renesting occurs if loss of the first nest occurs before mid-June (Whyte 1985), with the latest clutch initiation for Alberta being 6 to 10 July (Alberta Fish and Wildlife 1991a). The Piping Plover is a ground nester, and well-concealed eggs are laid in a shallow scrape lined with small

* See Appendix 1 for definitions of selected status designations. 
pebbles (Haig 1992). Clutches of four eggs are the norm (Haig 1992, Whyte 1985), although three-egg clutches are common, and five-egg clutches have been reported in the province (Wershler and Wallis 1987, I. Richardson, unpubl. data). The average clutch size of 3.62 to 4.00 reported for the KillarneyReflex Lakes area of Alberta over three years (Heckbert 1994, Heckbert and Cantelon 1996, I. Richardson, unpubl. data) is consistent with reports from other areas of the Great Plains (Prindiville Gaines and Ryan 1988, Whyte 1985, Espie et al. 1992). Males and females share in incubation of the eggs, which spans 26 to 28 days (Cairns 1982, Haig and Oring 1988b, Whyte 1985). The young leave the nest within several hours of hatching (Haig 1992), and are capable of sustained flight at about 28 days of age (Cairns 1982, Prindiville Gaines and Ryan 1988, Whyte 1985).

Reproductive success is highly variable between lakes, and between years across the breeding range of the Piping Plover (Goossen 1994). In Alberta, Hofman (1992) observed production of $0.7,0.6$, and 2.0 young/pair during brood surveys on Little Fish Lake in three different years. Heckbert (1994) found that 27.3 and $33.3 \%$ of nests on Killarney and Reflex Lakes, respectively, successfully hatched young in 1994. However, large differences in fledging success $(81.3 \%$ on Killarney, $31.8 \%$ on Reflex) yielded very different production estimates for the two lakes in the same year ( 0.5 young/pair on Reflex, 1.55 young/pair on Killarney). In 1995 , production on seven lakes in the same region of Alberta varied from 0 to 4.0 young/pair, and averaged 2.07 (Heckbert and Cantelon 1996). Elsewhere on the Great Plains, Espie et al. (1992) calculated hatching and fledging success of 2.8 and 2.0 chicks/pair, respectively, on Lake Diefenbaker in Saskatchewan. Whyte (1985) found that only $18.4 \%$ of nests on Big Quill Lake in
Saskatchewan hatched over a two year period, and that fledging success was less than $16 \%$. Ryan et al. (1993) summarized literature on the reproductive rate of Piping Plovers on the Great Plains across 32 site-years, and calculated fledging success to be 0.86 young/pair.

Most birds leave the Canadian prairies for wintering grounds along the Gulf Coast of the U. S., Mexico and the Caribbean (Haig 1992) by the end of the first week in August (Wershler and Wallis 1987, Whyte 1985). However, Heckbert (1994) reported adults with unfledged young on Killarney Lake as late as 16 August. Birds have been sighted in Saskatchewan as late as 1 October (Belcher 1961).

Estimates of fidelity by individually-marked adults to breeding areas on the Great Plains ranges between 42 and $71 \%$ for adults, but are typically less than $14 \%$ for juveniles (Goossen 1989, Haig and Oring 1988b,c, Root et al. 1992, Whyte 1985). Haig and Oring (1988c) demonstrated that fidelity is highest in areas with large amounts of suitable breeding habitat. Birds have been known to disperse up to $1,500 \mathrm{~km}$ from one breeding season to the next (Haig and Oring 1988c). Johnson and Baldassarre (1988) observed an annual return of $63 \%$ of marked birds to wintering areas on the Gulf of Mexico.

There are no estimates of longevity for Piping Plovers from the Great Plains. However, Wilcox (1959), who banded 1,173 adult birds over 20 years on the Atlantic coast, found that $28 \%$ of males and $13 \%$ of females lived to be five years or older, and that 12 birds achieved ages of between eight to 11 years. A single bird attained an age of 14 years (Wilcox 1962). 


\section{DISTRIBUTION}

1. Alberta. - The Piping Plover has a widespread, but sparse distribution across the aspen parkland, northern fescue grassland, and mixed-grass regions of southern Alberta. The first breeding record for the province was at an unspecified lake near Camrose (probably Miquelon Lake) in 1930 (Farley 1931). However, there were no extensive surveys of Piping Plover breeding sites prior to the 1980s. In 1986, Wershler and Wallis (1987) identified potential breeding sites from aerial photographs, and located plovers on 28 water bodies. Eleven of these sites were previously unknown breeding locations. One additional breeding site was identified in each of 1987 ("Metiskow" Lake, Wershler 1988) and 1988 (Killarney Lake, Wershler 1989). In 1991, the first international Piping Plover census was conducted across North America. In Alberta, 47 water bodies were surveyed. Plovers were detected on 27 (57.4\%) of lakes, with the highest counts being found on Killarney Lake (22 birds), followed closely by Dowling (21) and Handhills (20) Lakes (Hofman 1994). Several new breeding sites were discovered during the next few years, and the next international census in 1996 was extended to include 103 lakes. Plovers were found on 31 $(30.1 \%)$ water bodies, with the highest populations (54 birds) being detected on Dowling and Handhills Lakes (Bjorge 1996).

Overall, Piping Plovers have been reported from at least 60 water bodies in the province during the breeding season (Figure 1, Appendix 2). However, changing habitat conditions mean that not all lakes will support breeding pairs in any given year. Of 46 sites surveyed in both the 1991 and 1996 censuses, 16 supported breeding plovers in both years, whereas 10 sites had plovers in 1991 but not 1996, and four supported birds in 1996 but not in 1991 (Bjorge 1996). Furthermore, lakes that consistently support plover populations can vary widely in the number of birds present (Table 1). These variations probably result from differences in the availability of suitable nesting substrates, which tend to be localized on lakes and strongly affected by small variations in water levels.

2. Continental Range. - The breeding range of the Piping Plover is restricted to North America (Figure 2). Three distinct populations are recognized: the Atlantic coast population, which breeds from southwestern Newfoundland to South Carolina; the Great Lakes population, which is now restricted to southern Lake Superior and northwestern Lake Michigan; and the Great Plains population, which breeds from central Alberta to Lake of the Woods in Ontario, and south to northern Oklahoma (Haig 1992). The Atlantic coast population is considered to be a separate subspecies ( $\underline{\text { C. }} \underline{\text { m. melodus }}$ ) from the Great Lakes and Great Plains populations

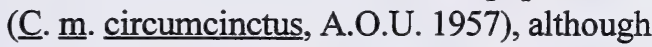
morphometric (Wilcox 1959) and electrophoretic (Haig and Oring 1988a) evidence cast doubt on distinctness of the subspecies. All populations are migratory, and winter on the Atlantic seaboard of the southeastern United States, along the Gulf Coast of the United States and Mexico, and on some Caribbean Islands. Limited banding information suggests that birds originating on the Great Plains winter primarily on the Gulf Coast (Haig and Oring 1985, 1988c). A single bird banded at Handhills Lake wintered for three consecutive years on Marco Island, on the Gulf Coast of Florida (Goossen 1990). Observations at inland sites during the migration period are limited, so most birds probably travel nonstop between breeding and wintering areas (Haig 1992). 


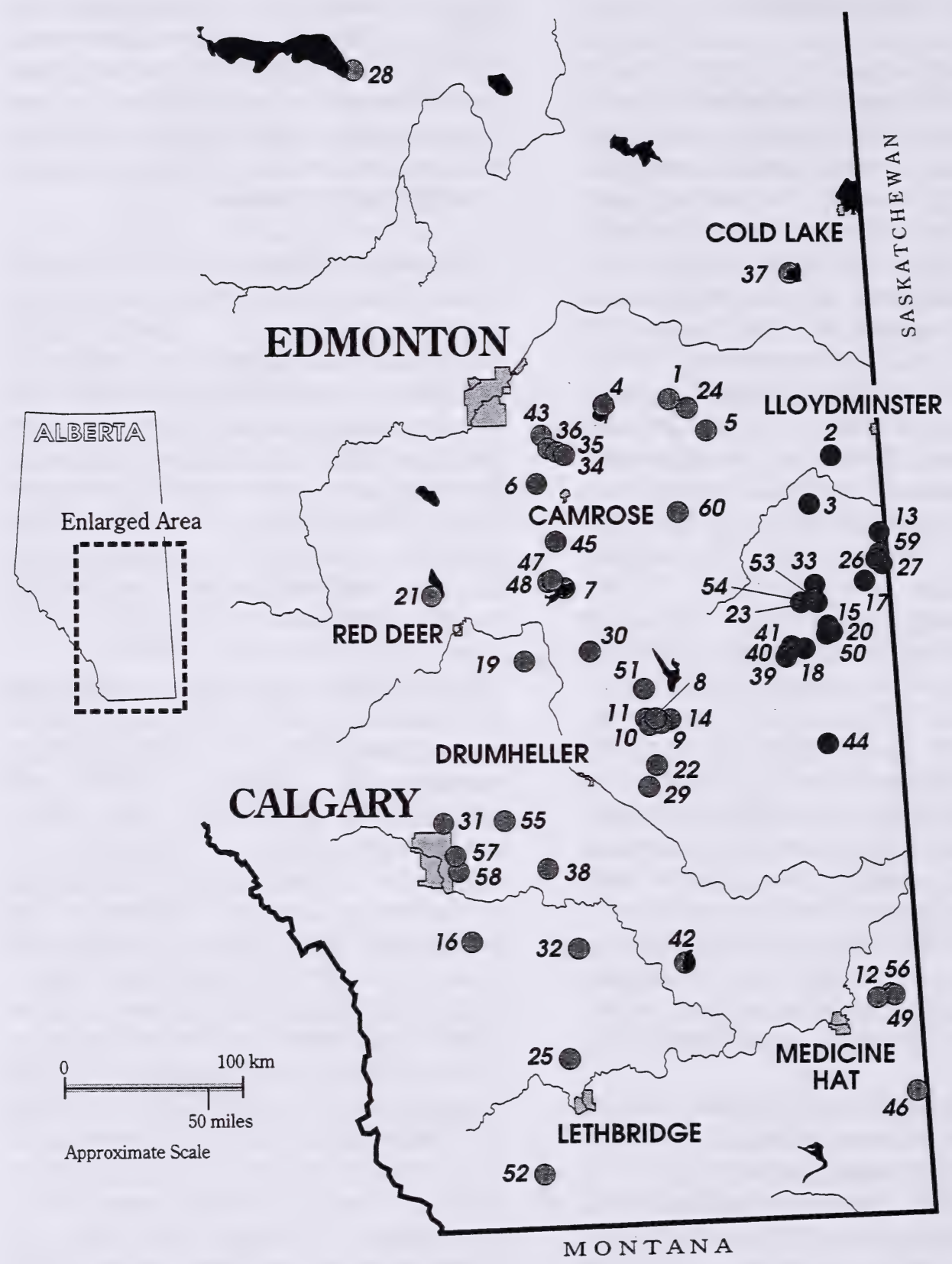

Figure 1. Distribution of water bodies where Piping Plovers have been recorded during the breeding season (1 May to 31 July) in Alberta (from Bjorge 1996, Hofman 1994, Alberta Fish and Wildlife 1991a and Wershler and Wallis 1987). See Appendix 2 for description of sites. 
Table 1. Number of adult Piping Plovers observed on selected lakes in Alberta between 1989 and $1996^{\mathrm{a}}$. Where repeat surveys were conducted in the same year, maximum numbers are given. Numbers in parentheses correspond to lake locations in Figure 1 and Appendix 2.

\begin{tabular}{|c|c|c|c|c|c|c|c|c|c|c|c|}
\hline \multirow[b]{2}{*}{ LAKE } & \multicolumn{11}{|c|}{ YEAR } \\
\hline & 1986 & 1987 & 1988 & 1989 & 1990 & 1991 & 1992 & 1993 & 1994 & 1995 & 1996 \\
\hline Chain (8-11) & 13 & 14 & 13 & 11 & 12 & 5 & 22 & 17 & 23 & 20 & 13 \\
\hline Chappice (12) & $17+$ & $11^{\mathrm{b}}$ & & 15 & 11 & 2 & 5 & 4 & 1 & & 1 \\
\hline Dowling (14) & 18 & & 18 & 15 & 13 & 21 & 34 & 39 & 58 & 35 & 54 \\
\hline Handhills (22) & 37 & 44 & 71 & 36 & 27 & 20 & 20 & 37 & 52 & 37 & 69 \\
\hline Killarney (26) & & & & $8-10$ & & 22 & & 29 & 48 & 40 & 25 \\
\hline Little Fish (29) & & $10-17$ & 18 & $41-49$ & 48 & 19 & 18 & 11 & 3 & 2 & 0 \\
\hline "Rider" (47) & 15 & & & 11 & 17 & 7 & 16 & 7 & 12 & 6 & 0 \\
\hline Rockeling Bay (48) & 18 & & & 30 & 22 & 6 & 9 & 12 & 17 & 13 & 0 \\
\hline W. Reflex (59) & $46+$ & $35+$ & & 20 & 21 & 12 & 11 & 16 & 28 & 37 & 19 \\
\hline
\end{tabular}

a sources: Bjorge (1996), Goossen (1991, 1994, in prep. and unpubl. data), Goossen and Biel (in prep.), Heckbert (1994), Heckbert and Cantelon (1996), Hofman (1990, 1991, 1992, 1993, 1994 and unpubl. data), Lord (1989), Wershler (1988, 1992), Wershler and Wallis (1987).

${ }^{\mathrm{b}}$ partial survey

\section{POPULATION SIZE AND TRENDS}

1. Alberta. - Although reliable estimates of historic provincial populations are lacking, there have been several population estimates derived for the Piping Plover in Alberta over the past two decades. Weseloh and Weseloh (1983) estimated a population of 47 to 54 pairs in the Dowling/Chain Lakes area, and suggested that the total population in Alberta was 100 to 110 pairs in the mid 1970 s. Wershler and Wallis (1987) surveyed 118 sites within the known breeding range, and counted at least 288 individuals. They estimated the total breeding population for the province to be at least 300 adults. Although extensive surveys were not conducted between 1988 and 1990, this estimate was reduced to $220+$ adults for these years, following extensive drought and reduced habitat suitability in the region (Alberta Fish and Wildlife 1991a, Goossen 1991).

The international Piping Plover census conducted in 1991 and 1996 provides the best measure of population size and trends in Alberta, and elsewhere in North America. In the 1991 survey, 47 water bodies were surveyed in the province, and 180 adults were observed (3.3\% of North American population). In 1996, 276 adults were observed, but almost twice as many sites were surveyed (103). However, 210 adults were found in 1996 on 46 water bodies that were also censused in 1991, suggesting an increase of 30 individuals ( $16.6 \%$ ) on these lakes over a five-year period (Bjorge 1996). Surveys in Alberta, and elsewhere (Haig et al. 1988, 


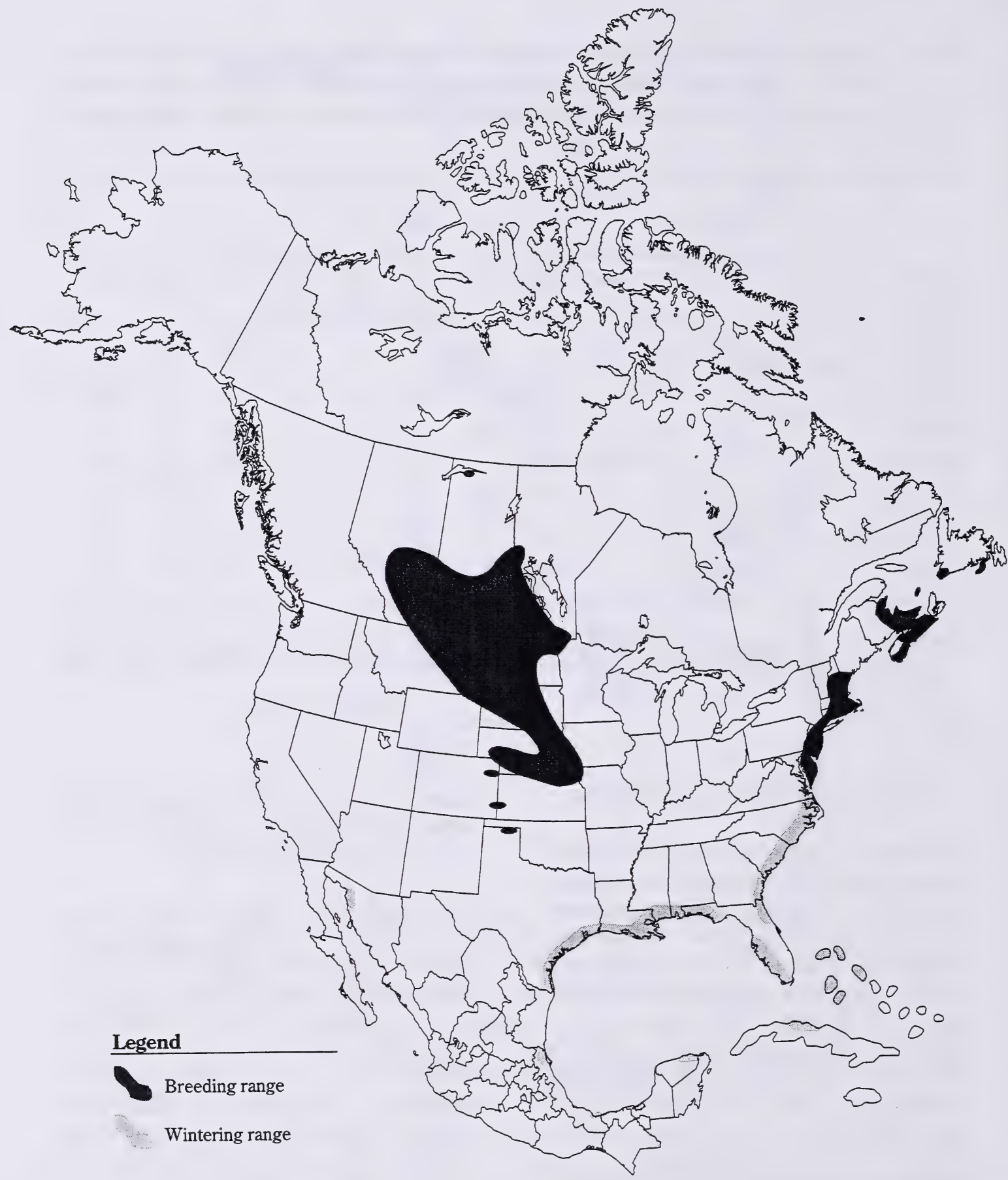

Figure 2. Breeding and wintering ranges of the Piping Plover (modified from Haig 1992). 
Ryan et al. 1993), have involved different amounts of effort and coverage. Furthermore, local and regional populations fluctuate with the availability of suitable nesting habitat. Population estimates derived from different studies are therefore difficult to compare, and it is unknown whether current and historical population sizes are similar. Nevertheless, current information suggests that between 220 and 350 adult Piping Plovers currently breed in Alberta during any given year (Alberta Fish and Wildlife 1991a), and that approximately half of this population occurs on nine lakes in the province (Table 1).

2. Other Areas. - Estimates of the historic population size of Piping Plovers in North America are lacking. The species is thought to have been hunted close to extinction prior to implementation of the Migratory Birds Convention in 1917 (Tyler 1929). Populations subsequently increased until about 1940, but have declined since that time (Sidle 1984, Tate 1981). During the past 50 years, populations have disappeared from most of the Great Lakes, from numerous historical breeding sites on the Atlantic coast, and from many areas on the periphery of the species' range on the Great Plains (Haig 1992). Haig et al. (1988) estimated the North American population of Piping Plovers to be 2020 to 2088 pairs, of which 576 to 644 pairs nested on the Canadian prairies. The 1991 international census tallied 5482 adults on the breeding grounds, with 1437 birds being located at 111 sites on the Canadian prairies (Haig and Plissner 1992). Preliminary information from the 1996 international census suggests that populations on the Great Plains have declined five to six percent from 1991 levels (J. Plissner, pers. comm.). This is a slower decline than the seven percent/year estimated by Ryan et al. (1993). At the latter rate, Piping Plover populations on the Great Plains would be extirpated in about 80 years.

\section{LIMITING FACTORS}

Limiting factors are considered to be those conditions which degrade habitat suitability, reduce survivorship of young or adults, or decrease nesting success of adults once they are established at a site. Although factors such as weather (Haig 1988b) may influence plover populations, the present discussion focuses on conditions that may be linked to human activities on, or near, Piping Plover habitats.

\section{Hydrology and Vegetation}

Encroachment. - The presence of suitable nesting habitat for Piping Plovers requires alternating periods of high and low water that removes vegetation and exposes gravel substrates on nesting beaches. Concern has been expressed that demands on water from agriculture and other industries, coupled with a loss of native vegetation surrounding water bodies, may be altering the normal hydrology of nesting basins in Alberta (Alberta Fish and Wildlife 1991a, Wershler 1992). Such demands might promote vegetation encroachment by reducing the frequency of high-water events. Wershler (1992) identified 15 sites in Alberta where low water levels and demands on ground water may reduce the suitability of Piping Plover habitat. These include areas where springs and seeps may be impacted. Two lakes (Little Fish and Rockeling Bay) were emphasized as sites where severe vegetation encroachment has reduced the population of breeding plovers.

Concern has also been expressed over projects that stabilize water levels to enhance recreational opportunities. Such projects are underway at Buffalo Lake, and have been proposed for Little Fish Lake (Goossen 1994). Stabilization of water levels for recreation or irrigation supply may also limit plover habitat on Lake Newell and Keho Lake (G. Erickson, 
pers. comm.). The typical practice of raising water levels to full supply level on reservoirs after birds have started nesting is particularly destructive to plovers. In some years, such practices have been known to eliminate much of the Piping Plover production on Lake Diefenbaker, Saskatchewan, which has supported the highest numbers of Piping Plovers in North America (Espie et al. 1992, Goossen 1994, Robinson and Hjertaas 1991).

\section{Industrial Development. - Wershler (1992)} suggested that the exploration and extraction of fossil fuels around plover breeding sites could pollute water and shorelines, deplete water levels or interfere with ground water dynamics, and eliminate surrounding vegetation. The direct impacts of oil and gas development on plover habitat are not well documented, but activity has been reported in close proximity to at least seven known breeding sites in Alberta. In addition, changes in water chemistry and beach substrates attributed to potassium sulphate development has been observed at several breeding locations in Saskatchewan, and possibly at Horseshoe Lake in Alberta (Wershler and Wallis 1987).

Despite fears of water contamination by agricultural chemicals or industrial development, chemical analysis of Piping Plover eggs in Alberta has revealed no significant organochlorine or polychlorinated biphenol (PCB) residues (Won 1988). Thus, industrial activities may affect the suitability of shorelines for nesting, but there is no evidence that chemical residues have impacted the breeding performance of Piping Plovers in this region.

3. Livestock Grazing. - Livestock can disturb nesting substrates, interfere with normal nesting behavior by established birds, and directly destroy eggs. In addition, young plovers may fall into deep hoof prints and be unable to escape (Wershler and Wallis 1987, Hofman 1992), and construction of dugouts adjacent to shorelines can foul nesting beaches, change basin hydrology and accelerate vegetative encroachment (Heckbert 1994).

Cattle impacts on shorelines generally increase with decreasing salinity (Harris 1986, Wershler and Wallis 1987). Even though most plover habitat on the Great Plains occurs on alkaline lakes, the impacts of grazing on plovers in this area can be substantial. Harris (1992) identified cattle disturbance as the primary threat to Piping Plover production on 21 lakes in Saskatchewan. Wershler (1992) documented grazing on shorelines of 15 Piping Plover lakes in Alberta, and deemed livestock activity to be a major impact on Dowling and Reflex Lakes. Heckbert and Cantelon (1996) also identified severe grazing impacts on Reflex Lake. Prindiville Gaines and Ryan (1988) found lower nest success on territories with evidence of cattle activity in North Dakota. This is consistent with Hofman (1992), who believed that the elimination of cattle from the shoreline of Little Fish Lake substantially increased breeding success between 1991 and 1992.

Livestock activity is one of the major factors limiting breeding production by Piping Plovers in Alberta, but there are a number of effective and inexpensive measures which can be employed to reduce such impacts. Specific projects designed to improve Piping Plover recruitment in livestock production areas are detailed in the "Recent Management in Alberta" section, below.

4. Human Disturbance. - $\mathrm{H}$ u $\mathrm{m}$ a $\mathrm{n}$ disturbance occurs through motorized off-road travel (all-terrain vehicles), or by nonmotorized, recreational use of beaches. Such 
disturbances may affect plovers by directly destroying nests and eggs, or by interfering with territorial establishment and other reproductive behaviors (Haig et al. 1988).

Studies on the Atlantic coast have documented decreased nest success on beaches with human disturbance. Cairns (1982) calculated that 0.7 to 1.6 chicks/pair fledged on human-disturbed beaches in Nova Scotia, compared to 1.3 to 2.1 chicks/pair on isolated beaches. Similarly, Flemming et al. (1988) reported fledging success to be 3.1 young/pair on lowdisturbance beaches, and 1.6 young/pair on beaches with high levels of disturbance. The authors speculated impacts on fledging success may result from reduced time spent foraging and increased vigilance by chicks in areas with frequent human activity.

Wershler and Wallis (1987) and Wershler (1992) reported evidence of off-road vehicles at three or four Alberta lakes, with the most activity occurring at the westernmost of the Reflex Lakes. Recreational use of beaches was believed to be a concern at Keho and Reflex Lakes, and potentially at Chappice, Dowling, Gooseberry, Little Fish and Handhills Lakes (Alberta Fish and Wildlife 1991a, Wershler 1992). Heckbert (1994) and Heckbert and Cantelon (1996) reported recreational activity at Killarney, "Metiskow", and especially, Reflex Lakes.

Most plovers in Alberta nest on lakes that are unattractive for recreation (Weseloh and Weseloh 1983), and human activities are generally restricted to a brief period during the summer. However, most plovers begin nesting in early May, so recreational activities later in the summer would likely disturb active nests or broods.

5. Predation. - Predation on eggs and chicks is probably the greatest source of reproductive failure in Piping Plovers on the Great Plains. Haig and Oring (1988b) reported that $40 \%$ of nests in Manitoba were lost to predators, whereas Whyte (1985) and Prindiville Gaines and Ryan (1988) observed that 72 and $93 \%$ of egg losses resulted from predation in Saskatchewan and North Dakota, respectively. Instances of predation are rarely observed, and the types of predators poorly documented (Haig et al. 1988). Red Foxes and Striped Skunks (Haig and Oring 1988b), American Crows (Heckbert 1994), and gulls (Heckbert and Cantelon 1996, Whyte 1985) are most often implicated on the Great Plains, but Black-billed Magpies, Great Horned Owls, Northern Harriers, Coyotes, Raccoons, weasels and domestic dogs have also been observed, or suspected of, preying upon eggs or young (Espie et al. 1992, Heckbert 1994, Whyte 1985).

Although the loss of eggs and chicks to predators is a natural process, there is evidence that urbanization and recreational use of beaches have increased populations of gulls, foxes and skunks in some areas (Haig 1985). Predation is currently a major cause of reproductive failure in this province, and research directed towards minimizing this impact (see "Recent Management in Alberta") may lead to simple management tools which can enhance reproductive success of Piping Plovers.

\section{Development of Habitat on the Winter} Range. - Piping Plovers spend only $30 \%$ of their annual cycle on the breeding grounds, so most mortality of adult birds probably occurs on wintering areas or during migration (Root et al. 1992). Events occurring far to the south of Alberta therefore have potential for major impacts on local Piping Plover populations.

There has been little quantification of the threats to Piping Plovers on the wintering 
grounds. However, a number of potential factors have been identified, including oil spills, recreational activities, dredging, construction of seawalls and jetties that affect normal beach dynamics, expansion of intercoastal waterways, beach restoration, and dune stabilization (Haig and Plissner 1992, Nicholls and Baldassarre 1990, U. S. Fish and Wildlife Service 1994). The relatively high fidelity of birds to wintering areas (Johnson and Baldasarre 1988) suggests that protection of traditional wintering sites from such threats should be an important component of recovery plans for this species (Haig et al. 1988, U. S. Fish and Wildlife Service 1994).

\section{STATUS DESIGNATIONS}

1. Alberta. - The Piping Plover was considered to be a "vulnerable" species in Alberta in 1985, because the known breeding population at that time was restricted to less than 10 water bodies (Alberta Fish and Wildlife 1985). Wershler and Wallis (1987) recommended a status of "threatened", based on small, localized breeding populations in the province, instability of breeding habitat, and declining continental populations. In 1987, the Piping Plover was classified as an "endangered" species under the Alberta Wildlife Act. In 1991, a draft management plan for this species in Alberta was prepared (Alberta Fish and Wildlife 1991a) with a suggested target of 300 adults/year over a fiveyear period. In the same year, the species was included on the "Red List" in Alberta, as a species in danger of declining to nonviable population size in the province (Alberta Fish and Wildlife 1991b). The "Red List" status was maintained in the 1996 review of the status of Alberta wildlife (Alberta Wildlife Management Division 1996). In both the 1991 and 1996 reviews, the "Red List" designation was based on declining continental populations, the small size of local breeding populations, and the need for protection and management of key nesting habitats in Alberta.

2. Other Areas. - The Piping Plover is listed as an endangered species under the Manitoba Endangered Species Act (B. Jones, pers. comm.). No such legislative framework exists in Saskatchewan, but the Piping Plover is included on a list of species at risk that is used as a planning tool for the protection of native fauna (E. Wiltse, pers. comm.).

In 1978, the Committee on the Status of Endangered Wildlife in Canada (COSEWIC) designated the Piping Plover as a nationally "threatened" species (Bell 1978). Persistent population declines and threats to breeding populations from human activities prompted this designation to be upgraded to "endangered" seven years later (Haig 1985). In 1988, two national recovery teams (Atlantic and Prairie) were established, and a detailed recovery plan was approved in principle in 1989. That plan was never formally published, and continues to be revised and updated. The plan currently sets the objective of 300 adults in Alberta, and 2426 adults on the Canadian prairies (Goossen et al., in prep.).

Sidle (1984) proposed that the Great Lakes population of the Piping Plover be designated as an "endangered" species in the United States, and that the breeding populations on the Atlantic coast and Great Plains, and wintering populations be designated as "threatened". The proposed designations were achieved in January 1986 (Federal Register 1985). In 1986, the U. S. Fish and Wildlife Service appointed the Atlantic coast and Great Lakes/Northern Great Plains recovery teams, which established targets of 1300 pairs of birds for a 15-year period on the U. S. Great Plains, and 150 pairs on the Great Lakes (Haig 
et al. 1988). The target for the U. S. Great Plains was later increased to 2300 pairs, and it has been proposed that the status of this population be changed to "endangered" (U. S. Fish and Wildlife Service 1994). It was believed that achievement of both the U. S. and Canadian recovery goals should ensure (with $95 \%$ probability) persistence of the species over the next 100 years (U. S. Fish and Wildlife Service 1994).

\section{RECENT MANAGEMENT IN ALBERTA}

Poor nesting success and low adult survivorship have been identified as the major factors influencing the decline of Piping Plover populations on the Great Plains (Root et al. 1992, Ryan et al. 1993). Ryan et al. (1993) estimated that annual production on the Great Plains is approximately 0.86 young/pair, whereas a stable population requires production of at least 1.13 young/pair. There is no practical way of increasing adult survivorship, so augmenting breeding production has been the goal of management efforts in many parts of the species' range. In Alberta, management activities have focused on several fronts:

1. Planning. - In 1991, a draft management plan for the Piping Plover was prepared (Alberta Fish and Wildlife 1991a). This document reviewed the status of the plover in Alberta, highlighted threats to plover populations on key breeding lakes, and suggested options available for managing local populations and habitats.

In 1992, the Alberta North American Waterfowl Management Plan (NAWMP) Centre commissioned a summary of Piping Plover management concerns on key lakes in Alberta, including identification of potential benefits and threats of NAWMP activities to plover populations (Wershler 1992). The report coincided with the formation of the Alberta Ad Hoc Piping Plover Group, with membership from the Alberta NAWMP Centre, Canadian Wildlife Service, Alberta Natural Resources Service, and Ducks Unlimited Canada. This group, which is now chaired by the Land Stewardship Centre of Canada, reviews and coordinates management of the Piping Plover in Alberta, and has cooperatively funded research into the biology and management of populations in this province (Heckbert 1994, Heckbert and Cantelon 1996, I. Richardson, in prep.). A review of priority vertebrate species in relation to NAWMP programs in Alberta rated the Piping Plover as the highest, and secondhighest ranking species in the prairie and aspen parkland biomes, respectively (Patriquin 1993).

\section{Habitat Securement, Protection and} Enhancement. - Habitat management for Piping Plovers has occurred in four locations: the "Rider" Lake/Rockeling Bay area, and Killarney, Little Fish, and Handhills Lakes.

Management at "Rider" Lake/Rockeling Bay and Killarney Lake has been primarily by the North American Waterfowl Management Plan. At "Rider" Lake/Rockeling Bay, 31 ha of uplands have been secured around traditional nesting areas, and $1.5 \mathrm{~km}$ of fence erected to eliminate cattle from nesting beaches (K. Schmitt, pers. comm.). In addition, burning and snow-packing of several hectares of beach were conducted in 1992 and 1993, in order to reduce vegetation encroachment (Goossen 1994). Current management in this area relates primarily to the stabilization of water levels on nearby Buffalo Lake. In high water years, Buffalo Lake backs up into "Rider" Lake and Rockeling Bay, thereby removing shoreline vegetation. In anticipation that such flooding 
would be eliminated by lake stabilization, infrastructure is currently being designed to periodically flood "Rider" Lake/Rockeling Bay to restore plover habitat. Securement of additional shoreline property will occur in conjunction with the water diversion project (K. Schmitt, pers. comm.).

Management on Killarney Lake has focused on elimination of cattle activity on shorelines. To date, 36 ha of uplands have been purchased, and $10 \mathrm{~km}$ of fencing erected to keep cattle away from the shoreline. In addition, a well and solar pump was provided to a landowner to provide an off-site water source for cattle. An additional $1.5 \mathrm{~km}$ of fencing, due for completion in 1997, will completely eliminate cattle access to the shoreline of Killarney Lake (B. Ilnicki, pers. comm.).

Following identification of livestock activity as a major impact on production of Piping Plovers at Little Fish Lake (Wershler 1988), Alberta Fish and Wildlife, with funding from the World Wildlife Fund and the Fish and Wildlife Trust Fund, erected fences around Little Fish Lake in 1990 and 1991 that virtually eliminated cattle damage in subsequent years (Hofman 1991). This project proceeded with cooperation of the landowner (Special Areas) and leasees, and included the construction of several dugouts to provide improved livestock watering.

Fencing to exclude cattle from nesting habitat on the western shore of Handhills Lake was initiated in the fall of 1996 through a grant from the Buck for Wildlife program. At that time, approximately $2.5 \mathrm{~km}$ of fence posts were erected, but high water during the spring of 1997 prevented completion of the project. Fencing should be completed by the fall of 1997 , or as soon as water levels recede (E. Hofman, pers. comm.).
3. Research. - In addition to the previouslydiscussed surveys, several research projects with applications for plover management have been conducted in the province. Heckbert (1994), and Heckbert and Cantelon (1996), studied the breeding biology of Piping Plovers in the eastern aspen parkland, with emphasis on identifying factors affecting breeding production. Heckbert and Cantelon (1996) also investigated the benefits of using predator exclosures around nests, and demonstrated that nest success increased from 1.7 to 3.5 young/nest when predator exclosures are applied (see also Melvin et al. 1992, Rimmer and Deblinger 1990). Similar results are being achieved with much smaller, portable enclosures, and a protocol for wide-scale implementation of enclosures is now being developed (I. Richardson, in prep.). Research has also been conducted into mapping substrates and establishing habitat suitability indices for Little Fish Lake (Wells and Lindberg 1991), modelling the hydrology of major Piping Plover lakes in the province $(R$. Wells and A. Murphy, unpubl. data), and determining the effectiveness of herbicides for controlling vegetation encroachment on shorelines (A. Murphy, pers. comm.).

\section{SYNTHESIS}

The Piping Plover is a widely-distributed but uncommon species in southern Alberta. Evidence suggests that the provincial population is about 300 adults, or up to five percent of the continental population. Population size and distribution are dynamic, varying from year to year with the availability of suitable habitat. This, coupled with variable and sporadic survey efforts, makes long-term population trends in the province impossible to determine reliably with current information.

Although continental populations have 
declined in recent years, the absence of discernable decreases in Piping Plover populations in Alberta, along with the continued discovery of new nesting locations, makes it unlikely that the species is in imminent danger of extirpation in the province. However, there are reasons to be cautious about the future of plover populations in Alberta. The provincial population is very small and more than half the breeding birds in any given year occur on a few key lakes. Furthermore, there are threats to habitat quality and breeding productivity that should not be ignored. Taken together, these factors suggest that the population in Alberta is highly vulnerable to environmental changes, particularly those that may result from human activities around traditional nesting basins.
Recent cooperative initiatives have greatly improved our understanding of the biology, distribution, population size and management of the Piping Plover in Alberta. However, current information on population trends in the province is weak, primarily because of the ongoing discovery of previously-unknown breeding sites. It is likely that most major breeding areas have now been identified, and that regular, systematic surveys of these sites will yield an accurate assessment of population trajectories in Alberta. Such surveys would also allow for regular. assessment of habitat conditions, in order that threats to Piping Plover populations in this province can effectively be monitored, and that appropriate management actions can be implemented. 


\section{LITERATURE CITED}

Alberta Fish and Wildlife. 1985. A policy for the management of threatened wildlife in Alberta. Alberta Fish and Wildlife, Edmonton, AB. 34 pp.

Alberta Fish and Wildlife. 1991a. Management plan for the Piping Plover in Alberta (final draft). Alberta Fish and Wildlife, Edmonton, AB. 67 pp.

Alberta Fish and Wildlife. 1991b. The status of Alberta wildlife. Alberta Fish and Wildlife, Edmonton, AB. 49 pp.

Alberta Wildlife Management Division. 1996. The status of Alberta wildlife. Alberta Natural Resources Service, Edmonton, AB. $44 \mathrm{pp}$.

Belcher, M. 1961. The birds of Saskatchewan. Sask. Nat. Hist. Soc. Spec. Publ. No. 3., Regina, SK. 76 pp.

Bell, F. H. 1978. The Piping Plover in Canada: status report. National Museum of Canada, Ottawa, ON.

Bjorge, R. R. 1996. The 1996 Piping Plover census in Alberta, executive summary. Unpubl. rept., Alberta Natural Resources Service, Parkland region, Red Deer, AB. 7 pp.

Cairns, W. E. 1982. Biology and behavior of breeding Piping Plovers. Wilson Bull. 94: 531-545.

COSEWIC. 1996. Canadian species at risk. Committee on the Status of Endangered Wildlife in Canada, Ottawa, ON. 18 pp.

Dundas, H. A. 1995. Breeding habitat selection by Piping Plovers in southern
Saskatchewan. Unpubl. M.Sc. thesis, University of Saskatchewan, Saskatoon, SK. $120 \mathrm{pp}$.

Espie, R. H. M., R. M. Brigham, and P. C. James. 1992. Breeding ecology of the Piping Plover at Lake Diefenbaker, Saskatchewan. Unpubl. rept. for Canadian Wildlife Service, Edmonton, AB. 31 pp.

Farley, F. L. 1931. Nesting of the Piping Plover Charadrius meloda in Alberta. Can. Field-Natur. 45: 21-22.

Federal Register. 1995. Endangered and threatened wildlife and plants; determination of endangered and threatened status for the Piping Plover; final rule. Federal Register 50: 50726-50734.

Flemming, S. P., R. D. Chiasson, P. C. Smith, P. J. Austin-Smith, and R. P. Bancroft. 1988. Piping Plover in Nova Scotia related to its reproductive and behavioural responses to human disturbance. J. Field Ornithol. 59: 321-330.

Goossen, J. P. 1989. Prairie Piping Plover conservation: first annual report (1988). Unpubl. rept., Canadian Wildlife Service, Edmonton, AB. 19 pp.

Goossen, J. P. 1991. Prairie Piping Plover conservation: third annual report (1990). Unpubl. rept., Canadian Wildlife Service, Edmonton, AB. 28 pp.

Goossen, J. P. 1994. Prairie Piping Plover conservation: 1992 and 1993. Unpubl. draft rept., Canadian Wildlife Service, Edmonton, AB. 34 pp.

Goossen, J. P. In prep. Population dynamics of Piping Plovers in Alberta. Canadian Wildlife Service, Edmonton, AB. 
Goossen, J. P., D. L. Amirault, S. Richard, J. S. Boates, J. Brazil, R. Bjorge, G. N. Corbett, F. R. Curley, S. Flemming, W. Harris, L. Heyens, M. Huot, R. Jones, P. Laporte, R. I. G. Morrison, and E. Wiltse. In prep. The Canadian Piping Plover Recovery Plan. RENEW, Ottawa, ON.

Goossen, J. P., and R. Biel. In prep. Population status, distribution, nesting and conservation of Piping Plovers in the Buffalo Lake area, Alberta. Canadian Wildlife Service, Edmonton, AB.

Haig, S. M. 1985. The status of the Piping Plover in Canada. Committee on the Status of Endangered Wildlife in Canada, National Museums of Canada, Ottawa, ON.

Haig, S. M. 1992. Piping Plover. In Birds of North America, No. 2 (A. Poole, P. Stettenheim and F. Gill, eds.). Academy of Natural Sciences, Philadelphia, PA. 18 pp.

Haig, S. M., W. Harrison, R. Lock, L. Pfannmuller, E. Pike, M. Ryan, and J. Sidle. 1988. Recovery plan for Piping Plovers (Charadrius melodus) of the Great Lakes and northern Great Plains. U. S. Fish and Wildlife Service, Twin Cities, MN. 160 pp.

Haig, S. M., and L. W. Oring. 1985. Distribution and status of the Piping Plover throughout the annual cycle. J. Field Ornithol. 56: 334-345.

Haig, S. M., and L. W. Oring. 1988a. Genetic differentiation of Piping Plovers across North America. Auk 105: 260-267.

Haig, S. M., and L. W. Oring. 1988b. Mate, site, and territory fidelity in Piping Plovers. Auk 105: 268-277.

Haig, S. M., and L. W. Oring. 1988c.
Distribution and dispersal in the Piping Plover. Auk 105: 630-638.

Haig, S. M., and J. H. Plissner. 1992. 1991 International Piping Plover census. U. S. Fish and Wildlife Service, Ft. Snelling, MN. $148 \mathrm{pp}$.

Harris, W. C. 1992. Impact assessment of Piping Plover breeding habitat on twentyone lakes in southern Saskatchewan. Unpubl. rept. for Saskatchewan Wetland Conservation Corporation, Regina, SK. 10 pp.

Heckbert, M. D. 1994. Piping Plover (Charadrius melodus) ecology and conservation in Alberta (1994): Reflex Lake and Killarney Lake field report. Unpubl. rept., Alberta Fish and Wildlife Services, Northeast Region. 152 pp.

Heckbert, M. D., and K. D. Cantelon. 1996. Piping Plover (Charadrius melodus) ecology and conservation in Alberta (1995): eastcentral Alberta field report. Unpubl. rept. for Alberta Fish and Wildlife Services and Alberta NAWMP Centre, Edmonton, AB. $163 \mathrm{pp}$.

Hofman, D. E. 1990. 1990 Piping Plover survey, Little Fish Lake, Alberta. Unpubl. rept., Alberta Fish and Wildlife Division, Red Deer, AB. 18 pp.

Hofman, D. E. 1991. 1991 Piping Plover survey, Little Fish Lake, Alberta. Unpubl. rept., Alberta Fish and Wildlife Division, Red Deer, AB. 22 pp.

Hofman, D. E. 1992. 1992 Piping Plover survey, Little Fish Lake, Alberta. Unpubl. rept., Alberta Fish and Wildlife Division, Red Deer, AB. 16 pp. 
Hofman, D. E. 1993. 1993 Piping Plover survey, Little Fish Lake, Alberta. Unpubl. rept., Alberta Fish and Wildlife Division, Red Deer, AB. 8 pp.

Hofman, D. E. 1994. The 1991 Piping Plover census in Alberta. Pp. 43-47 in The 1991 international Piping Plover census in Canada (S. P. Flemming, ed.). Can. Wildl. Serv. Occ. Paper No. 82.

$59 \mathrm{pp}$.

Johnson, C. M., and G. A. Baldassarre. 1988. Aspects of the wintering ecology of Piping Plovers in coastal Alabama. Wilson Bull. 100: 214-223.

Lord, S. 1989. Piping Plover surveys at Little Fish Lake. Unpubl. rept., Canadian Wildlife Service, Edmonton, AB. 10 pp.

Melvin, S. M., L. H. McIvor, and C. R. Griffin. 1992. Predator exclosures: a technique to reduce predation at Piping Plover nests. Wildl. Soc. Bull. 20:143-148.

National Research Council. 1995. Science and the Endangered Species Act. National Academy Press, Washington, DC. 271 pp.

Nicholls, J. L., and G. A. Baldassarre. 1990. Winter distribution of Piping Plovers along the Atlantic and Gulf coasts of the United States. Wilson Bull. 102: 400-412.

Patriquin, D. L. 1993. An overview of priority vertebrate species and habitats in relation to NAWMP program delivery in Alberta. Alberta NAWMP Centre, NAWMP-006, Edmonton, AB. 77 pp.

Pinel, H. W., W. W. Smith, and C. R. Wershler. 1991. Alberta birds, 1971-1980. Provincial Museum of Alberta, Nat. Hist. Occ. Pap. No. 13. Edmonton, AB. 243 pp.
Prindiville Gaines, E., and M. R. Ryan. 1988. Piping Plover habitat use and reproductive success in North Dakota. J. Wildl. Manage. 52: 266-273.

Rimmer, D. W., and R. D. Deblinger. 1990. Use of predator exclosures to protect Piping Plover nests. J. Field Ornithol. 61: 217-223.

Robinson, L. C., and D. Hjertaas. 1991. The effect of water level management on the Piping Plover at Lake Diefenbaker. Unpubl. rept., Saskatchewan Natural Resources, Regina, SK. 35 pp.

Root, B. G., M. R. Ryan, and P. M. Mayer. 1992. Piping Plover survival in the Great Plains. J. Field Ornithol. 63: 10-15.

Ryan, M. R., B. G. Root, and P. M. Mayer. 1993. Status of Piping Plovers in the Great Plains of North America: a demographic simulation model. Conserv. Biol. 7: 581585 .

Sidle, J. 1984. Endangered and threatened wildlife and plants; Piping Plover proposed as an endangered and threatened species. Federal Register 49: 44712-44715.

Tate, J. 1981. The blue list for 1981. Am. Birds 35: 3-10.

Tyler, W. M. 1929. Piping Plover. Pp. 236246 in Life histories of North American shorebirds (A. C. Bent, ed.). U. S. National Museum Bulletin No. 146., Washington, DC.

U. S. Fish and Wildlife Service. 1994. Draft revised recovery plan for Piping Plovers, Charadrius melodus, breeding on the Great Lakes and Northern Great Plains of the United States. U. S. Fish and Wildlife Service, Twin Cities, MN. 121 pp. 
Wells, R. E., and M. Lindberg. 1991. Little Fish Lake habitat classification. Unpubl. rept., Alberta Land Information Division, Edmonton, AB. 20 pp.

Wershler, C. R. 1988. Piping Plover studies Alberta 1987. Unpubl. rept. for Alberta Recreation and Parks, World Wildlife Fund Canada, Alberta Fish and Wildlife, and Canadian Wildlife Service. Calgary, AB. $33 \mathrm{pp}$.

Wershler, C. 1989. Piping Plover surveys in Alberta, 1989. Unpubl. rept. for Alberta Fish and Wildife, Edmonton, AB. 16 pp.

Wershler, C. R. 1992. An analysis of Piping Plover management concerns in Alberta. Unpubl. rept. for Alberta NAWMP Centre, Edmonton, AB. 56 pp.

Wershler, C, and C. Wallis. 1986. Status of the Piping Plover in Alberta, 1986. Unpubl. rept. for World Wildlife Fund Canada and
Canadian Wildlife Service, Calgary, AB. 54 pp.

Weseloh, D. V., and L. M. Weseloh. 1983. Numbers and nest site characteristics of the Piping Plover in central Alberta, 1974-1977. Blue Jay 41: 155-161.

Whyte, A. J. 1985. Breeding biology of the Piping Plover (Charadrius melodus) in central Saskatchewan. Unpubl. M.Sc. thesis, University of Saskatchewan, Saskatoon, SK. 53 pp.

Wilcox, L. 1959. A twenty year banding study of the Piping Plover. Auk 76: 129-152.

Wilcox, L. 1962. Oldest known shorebird in North America. EBBA News 25: 45-46.

Won, H. T. 1988. Analysis of Piping Plover egg samples for OCs and PCBs. Unpubl. Can. Wildl. Serv. Rept. 88-12. 21 pp. 


\section{A. Status of Alberta Wildlife color lists (after Alberta Wildlife Management Division 1996)}

\begin{tabular}{|l|l|}
\hline Red & $\begin{array}{l}\text { Current knowledge suggests that these species are at risk. These species have declined, or are } \\
\text { in immediate danger of declining, to nonviable population size }\end{array}$ \\
\hline Blue & $\begin{array}{l}\text { Current knowledge suggests that these species may be at risk. These species have undergone } \\
\text { non-cyclical declines in population or habitat, or reductions in provincial distribution }\end{array}$ \\
\hline Yellow & $\begin{array}{l}\text { Species that are not currently at risk, but may require special management to address concerns } \\
\text { related to naturally low populations, limited provincial distributions, or demographic/life history } \\
\text { features that make them vulnerable to human-related changes in the environment }\end{array}$ \\
\hline Green & $\begin{array}{l}\text { Species not considered to be at risk. Populations are stable and key habitats are generally } \\
\text { secure }\end{array}$ \\
\hline Undetermined & Species not known to be at risk, but insufficient information is available to determine status \\
\hline
\end{tabular}

\section{B. Alberta Wildlife Act}

Species designated as "endangered" under the Alberta Wildlife Act include those defined as "endangered" or "threatened" by A Policy for the Management of Threatened Wildlife in Alberta (Alberta Fish and Wildlife 1985):

\begin{tabular}{|l|l|}
\hline Endangered & A species whose present existence in Alberta is in danger of extinction within the next decade \\
\hline Threatened & $\begin{array}{l}\text { A species that is likely to become endangered if the factors causing its vulnerability are not } \\
\text { reversed }\end{array}$ \\
\hline
\end{tabular}

\section{Committee on the Status of Endangered Wildlife in Canada (after COSEWIC 1996)}

\begin{tabular}{|l|l|}
\hline Extirpated & A species no longer existing in the wild in Canada, but occurring elsewhere \\
\hline Endangered & A species facing imminent extirpation or extinction \\
\hline Threatened & A species likely to become endangered if limiting factors are not reversed \\
\hline Vulnerable & $\begin{array}{l}\text { A species of special concern because of characteristics that make it particularly sensitive to } \\
\text { human activities or natural events }\end{array}$ \\
\hline Not at Risk & A species that has been evaluated and found to be not at risk \\
\hline Indeterminate & A species for which there is insufficient scientific information to support status designation \\
\hline
\end{tabular}

\section{United States Endangered Species Act (after National Research Council 1995)}

\begin{tabular}{|l|l|}
\hline Endangered & Any species which is in danger of extinction throughout all or a significant portion of its range \\
\hline Threatened & $\begin{array}{l}\text { Any species which is likely to become an endangered species within the foreseeable future } \\
\text { throughout all or a significant portion of its range }\end{array}$ \\
\hline
\end{tabular}


APPENDIX 2. Names and locations ${ }^{2}$ of 60 lakes in Alberta where Piping Plovers have been observed during the breeding season (1 May to 31 July). Lake numbers correspond to points in Figure 1.

\begin{tabular}{|l|c|}
\hline \multicolumn{1}{|c|}{ LAKE } & LOCATION \\
\hline 1. Akasu & $\mathrm{T} 52, \mathrm{R} 13$ \\
\hline 2. Albert & $\mathrm{T} 48, \mathrm{R} 3-4$ \\
\hline 3. Baxter & $\mathrm{T} 45, \mathrm{R} 5$ \\
\hline 4. Beaverhill & $\mathrm{T} 51-52, \mathrm{R} 17-18$ \\
\hline 5. Birch & $\mathrm{T} 50, \mathrm{R} 11$ \\
\hline 6. Bittern & $\mathrm{T} 47, \mathrm{R} 21-22$ \\
\hline 7. Buffalo & $\mathrm{T} 40-41, \mathrm{R} 20-21$ \\
\hline 8. Chain \#1 (Pearl) & $\mathrm{S} 29, \mathrm{~T} 32, \mathrm{R} 15$ \\
\hline 9. Chain \#3 (Clear) & $\mathrm{T} 32, \mathrm{R} 15$ \\
\hline 10. Chain \#4 & $\mathrm{S} 1, \mathrm{~T} 33, \mathrm{R} 16$ \\
\hline 11. Chain \#6 & $\mathrm{S} 15, \mathrm{~T} 33, \mathrm{R} 16$ \\
\hline 12. Chappice & $\mathrm{S} 16, \mathrm{~T} 14, \mathrm{R} 3$ \\
\hline 13. Cipher & $\mathrm{T} 43, \mathrm{R} 1$ \\
\hline 14. Dowling & $\mathrm{T} 32, \mathrm{R} 14-15$ \\
\hline 15. Foster & $\mathrm{S} 31, \mathrm{~T} 37, \mathrm{R} 4$ \\
\hline 16. Frank & $\mathrm{T} 18-19, \mathrm{R} 27-28$ \\
\hline 17. Gillespie & $\mathrm{S} 23, \mathrm{~T} 40, \mathrm{R} 2$ \\
\hline 18. Gooseberry & $\mathrm{T} 36, \mathrm{R} 6$ \\
\hline 19. Goosequill & $\mathrm{S} 1, \mathrm{~T} 36, \mathrm{R} 23$ \\
\hline 20. Greenlee & $\mathrm{S} 29, \mathrm{~T} 37, \mathrm{R} 4$ \\
\hline 21. Gull & $\mathrm{T} 40, \mathrm{R} 28$ \\
\hline 22. Handhills & $\mathrm{T} 29, \mathrm{R} 15-16$ \\
\hline 23. Horseshoe & $\mathrm{T} 39, \mathrm{R} 6$ \\
\hline 24. Junction & $\mathrm{T} 51-52, \mathrm{R} 12$ \\
\hline 25. Keho & $\mathrm{S} 31, \mathrm{~T} 11, \mathrm{R} 22$ \\
\hline 26. Killarney & $\mathrm{T} 41, \mathrm{R} 1$ \\
\hline 27. Leanne & $\mathrm{S} 34, \mathrm{~T} 41, \mathrm{R} 1$ \\
\hline 28. Lesser Slave & \\
\hline 29. Little Fish & Towden \\
\hline 30. L16 \\
\hline
\end{tabular}

\begin{tabular}{|l|c|}
\hline \multicolumn{1}{|c|}{ LAKE } & LOCATION \\
\hline 31. McDonald & $\mathrm{T} 26, \mathrm{R} 29$ \\
\hline 32. McGregor & $\mathrm{T} 18, \mathrm{R} 21$ \\
\hline 33. "Metiskow" & $\mathrm{S} 10, \mathrm{~T} 40, \mathrm{R} 5$ \\
\hline 34. Miquelon \#1 (SE) & $\mathrm{T} 49, \mathrm{R} 20$ \\
\hline 35. Miquelon \#2 (Middle) & $\mathrm{T} 49, \mathrm{R} 20$ \\
\hline 36. Miquelon \#3 (NW) & $\mathrm{T} 49, \mathrm{R} 20-21$ \\
\hline 37. Muriel & $\mathrm{T} 59-60, \mathrm{R} 5$ \\
\hline 38. Namaka & $\mathrm{T} 23, \mathrm{R} 23-24$ \\
\hline 39. Neutral Hills A & $\mathrm{S} 4, \mathrm{~T} 36, \mathrm{R} 7$ \\
\hline 40. Neutral Hills B1 & $\mathrm{S} 9, \mathrm{~T} 36, \mathrm{R} 7$ \\
\hline 41. Neutral Hills C1 & $\mathrm{S} 27, \mathrm{~T} 36, \mathrm{R} 7$ \\
\hline 42. Newell & $\mathrm{S} 1, \mathrm{~T} 17, \mathrm{R} 15$ \\
\hline 43. Oliver & $\mathrm{T} 50, \mathrm{R} 21$ \\
\hline 44. Piper & $\mathrm{S} 2, \mathrm{~T} 30, \mathrm{R} 5$ \\
\hline 45. Red Deer & $\mathrm{T} 43-44, \mathrm{R} 21-22$ \\
\hline 46. Reesor & $\mathrm{T} 8, \mathrm{R} 1$ \\
\hline 47. "Rider" & $\mathrm{T} 41, \mathrm{R} 20$ \\
\hline 48. Rockeling Bay & $\mathrm{T} 41, \mathrm{R} 20$ \\
\hline 49. Sam & $\mathrm{S} 6, \mathrm{~T} 14, \mathrm{R} 2$ \\
\hline 50. Sounding & $\mathrm{T} 37, \mathrm{R} 4$ \\
\hline 51. Spiers & $\mathrm{S} 8, \mathrm{~T} 34, \mathrm{R} 16$ \\
\hline 52. St. Mary Reservoir & $\mathrm{T} 4, \mathrm{R} 24$ \\
\hline 53. Sunken & $\mathrm{T} 39, \mathrm{R} 5$ \\
\hline 54. Unnamed & $\mathrm{S} 2, \mathrm{~T} 39, \mathrm{R} 5$ \\
\hline 55. Unnamed & $\mathrm{S} 9, \mathrm{~T} 26, \mathrm{R} 25$ \\
\hline 56. Unnamed & $\mathrm{S} 34, \mathrm{~T} 13, \mathrm{R} 2$ \\
\hline 57. Unnamed & $\mathrm{S} 5, \mathrm{~T} 24, \mathrm{R} 28$ \\
\hline 58. Unnamed & $\mathrm{T} 23, \mathrm{R} 28$ \\
\hline 59. W. Reflex & $\mathrm{T} 42-43, \mathrm{R} 1$ \\
\hline 60. Whitewater & \\
\hline
\end{tabular}

${ }^{\text {a }}$ locations are given as section(S), township(T), range(R). Section numbers are provided only for small water bodies, or for localized site records on larger basins. All locations are west of the fourth meridian, except Lesser Slave Lake which is west of the fifth meridian. 


\section{List of Titles In This Series}

(as of September 1997)

No. 1 Status of the Piping Plover (Charadrius melodus) in Alberta, by David R. C. Prescott. 19 pp.

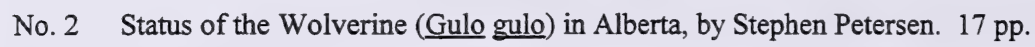

No. 3 Status of the Northern Long-eared Bat (Myotis septentrionalis) in Alberta, by M. Carolina Caceres and M. J. Pybus. 19 pp.

No. 4 Status of the Ord's Kangaroo Rat (Dipodomys ordii) in Alberta, by David L. Gummer. 16 pp.

No. 5 Status of the Eastern Short-horned Lizard (Phrynosoma douglassii brevirostre) in Alberta, by Janice D. James, Anthony P. Russell and G. Lawrence Powell. 20 pp.

No. 6 Status of the Prairie Rattlesnake (Crotalus viridis viridis) in Alberta, by Sheri M. Watson and Anthony P. Russell. 26 pp.

No. 7 Status of the Swift Fox (Vulpes velox) in Alberta, by Susan E. Cotterill. $17 \mathrm{pp}$.

No. 8 Status of the Peregrine Falcon (Falco peregrinus anatum) in Alberta, by Petra Rowell and David P. Stepnisky. In Preparation.

No. 9 Status of the Northern Leopard Frog (Rana pipiens) in Alberta, by Greg Wagner. In Preparation.

No. 10 Status of the Sprague's Pipit (Anthus spragueii) in Alberta, by David R. C. Prescott. 14 pp.

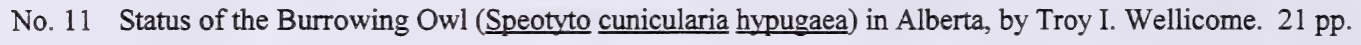


NOTES 
NOTES 
National Library of Canada

Bibliothène nationale du Canada

3 3286513566030 